\title{
CHROMOSOMES OF CRUCIFERAE I. DESCURAINIA ${ }^{1}$
}

\author{
J. T. Baldwin, Jr. and Jean Marshall Campbell
}

As understood by Schulz (1924), Descurainia Webb \& Berthelot is a natural assemblage of 43 species of annual and biennial cruciferous plants. Detling (1939) revised the North American species of the genus. Interpreting the species broadly on morphologic, ecologic, and geographic evidence, he regards "the subspecies as the product of the selective action of a particular environment" and, accordingly, recognized for Descurainia in North America 9 native and 1 adventive species. (Fernald [1940] claims that Detling, at least in some instances, incorrectly used the term subspecies "in the sense of the long-established term varietas.") Southwestern United States is the distributional center of the native representatives of the genus.

Dr. LeRoy E. Detling sent seeds collected from wild plants of four species and ten subspecies of Descurainia. Plants from those seeds were grown in the Botanical Gardens of the University of Michigan. Chromosomes of the plants were counted at metaphase in leaf smears prepared by the method of Baldwin (1939).

Chromosomes and the plants.-The chromosomes of Descurainia are uniformly small. The chromosome numbers form, with the exception of one report, a regular polyploid series founded on 7 .

Previous workers have published chromosome numbers for four species of the genus. Two of those species are South American: D. Cumingiana (Fisch \& Meyer) Prantl, with 14 somatic (Manton, 1932), 7 gametic (Jaretzky, 1932) chromosomes; D. myriophylla (Willd.) Fries, with 14 and, in some cells, 28 somatic chromosomes (Manton, 1932). The North American representatives of Descurainia for which chromosome numbers are known are given below as interpreted systematically by Detling. Data on geographic occurrence are taken from that author. Detling's herbarium numbers and the places of collection are put in brackets.

D. Sophia (L.) Webb, the type species, is an annual or biennial plant of the Old World and is now distributed throughout the United States, Canada, and Alaska. Manton (1932) reported for the species 28 and, in some cells, 56 somatic chromosomes. Jaretzky (1932) found 14 gametic chromosomes. Mayor (1934) emphasized the difficulty of counting the chromosomes of this plant and provisionally reported 10 gametic, 20 somatic chromosomes for the species, designated by him Sisymbrium Sophia L. The present writers determined a $2 n$-number of 28 for the species [Detling 2217, Mountain Home, Idaho] (fig. 1).

D. Richardsonii (Sweet) Schulz is biennial and occurs, for the most part, in the mountains of the western United States; one subspecies is in the northern plains. Two collections of subspecies vis-

${ }^{1}$ Received for publication July 17, 1940.

Papers from the Department of Botany of the University of Michigan, No. 723. cosa (Rydb.) Detl. [Detling 2257, Targhee Pass, Idaho; Detling 2213, Hilgard, Oregon] were found during this study to have 14 somatic chromosomes (fig. 2), subspecies procera (Greene) Detl. [Detling 2263, Howard Springs, Targhee Pass, Idaho] to have a $2 n$-number of 28 (fig. 3), and subspecies incisa (Engelm.) Detl. [Detling 2380, Flagstaff, Arizona], a $2 n$-number of 42 (fig. 4). It is clear that these subspecies are separated by polyploid differences. Consideration of the ranges given by Detling shows that the diploid viscosa and the hexaploid incisa occupy geographic areas of approximately the same magnitude, the latter subspecies being more southern in its occurrence but extending into the range of viscosa; and that, of these three subspecies, the tetraploid procera has the most restricted range and occurs almost entirely within the region where both incisa and viscosa are found.

D. obtusa (Greene) Schulz is an aggregate of strict, coarse, biennial plants mostly in the mountains or on the high plateaus of southwestern United States and northern Mexico. The present authors found that subspecies typica Detl. [Detling 2381, Williams, Arizona] has $2 n=14$ (fig. 5), and that subspecies brevisiliqua Detl. [Detling 2375, Gonzales, New Mexico, the type collection; Detling 2374, Thoreau, New Mexico] has $2 n=42$ (fig. 6). The diploid typica has a greater geographic range than the hexaploid brevisiliqua. Most of the range of the diploid is south of that of the hexaploid.

D. pinnata (Walt.) Britt. is a group of annual plants. "Evolution within this species seems to have followed two distinct lines, giving rise to one complex of subspecies in the hot arid regions of the Southwest and another complex in the more northern cooler and frequently moister regions of the Rocky Mountains, the Pacific Northwest and Canada" (Detling, 1939). The two complexes intergrade geographically and morphologically. Sometimes the northern association is segregated as $D$. brachycarpa (Richards) Schulz. The subspecies halictorum (Cockerell) Detl. includes both glandular and non-glandular plants; the plants differ in chromosome number. Cockerell (1901) gave specific rank to the non-glandular one. The authors found the glandular plant [Detling 2291, Boulder, Wyoming; Detling 2300, Red Desert, Wyoming] to have 42 somatic chromosomes (fig. 7), the non-glandular one [Detling 2360, Mesa Verde, Colorado] to have 28 somatic chromosomes (fig. 8). Likewise, subspecies glabra (Woot. \& Standl.) Detl. [Detling 2387, Mojave Desert, California] was discovered to have a $2 n$-number of 28 (fig. 9). Subspecies Menziesii (DC.) Detl. was investigated by Manton (1932), who gave the plant specific status and reported for it 28 somatic chromosomes. The present authors counted the chromosomes of three other subspecies: subspecies intermedia (Rydb.) Detl. 

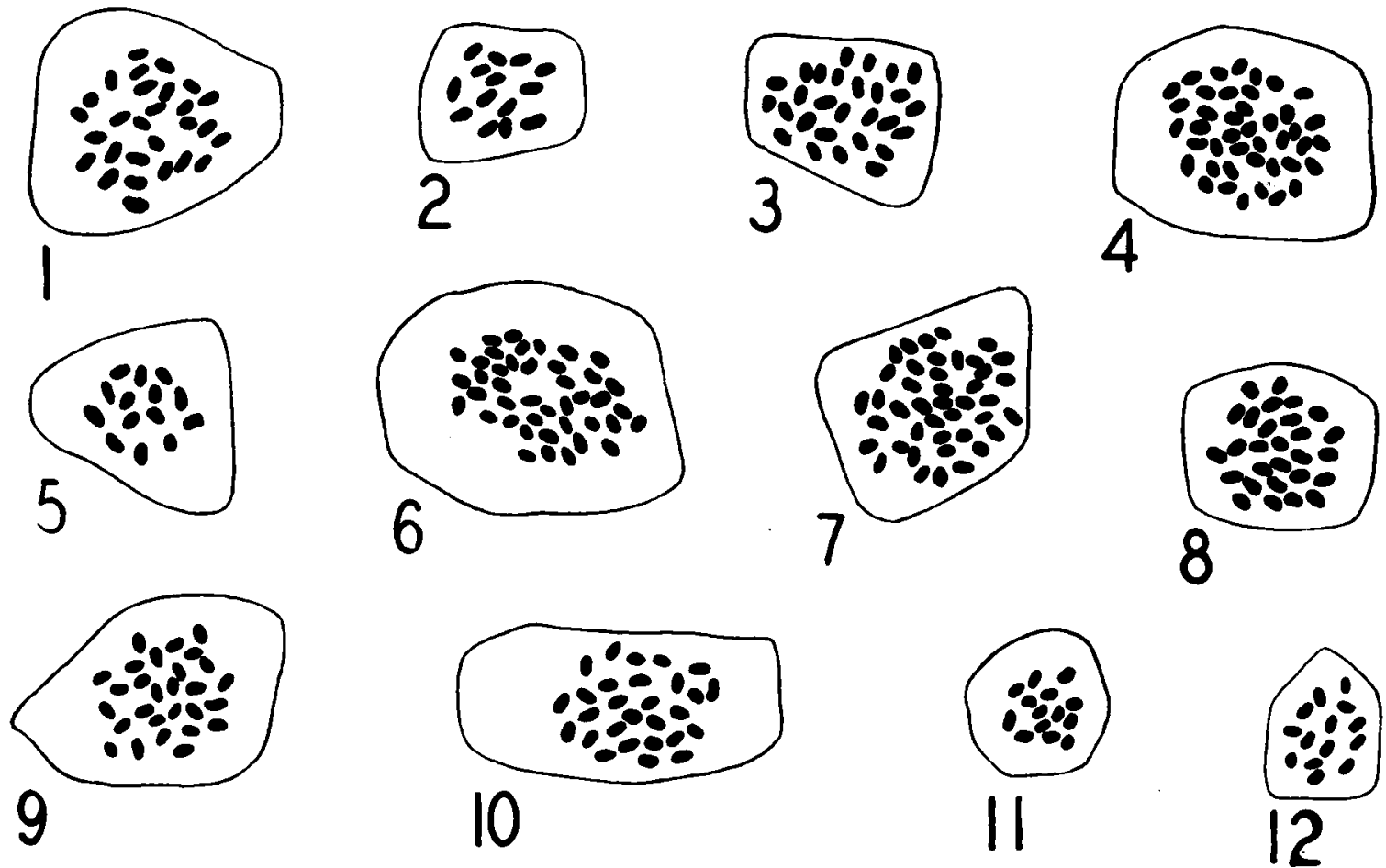

Fig. 1-12. Chromosomes of Descurainia.-Fig. 1. D. Sophia, $2 n=28 .-$ Fig. 2-4. D. Richardsonii, 2n $=14,28$, and 4.2.-Fig. 5-6. D. obtusa, $2 n=14$ and 42.-Fig. $7-12$. D. pinnuta, $2 n=42,28$, and 14. Magnification ca. $2,000 \times$; reproduced as drawn.

[Detling 2349, Uncompahgre River, Colorado], $2 n=28$ (fig. 10); subspecies Nelsonii (Rydb.) Detl. [Detling 2277, type locality, Lava Creek, near Wraith Falls, Yellowstone National Park, Wyoming], $2 n=14$ (fig. 11); subspecies filipes (Gray) Detl. [Detling 2303, 27 miles east of Rawlins, Wyoming; Detling 2205, confluence of Deschutes and Columbia Rivers, Oregon: equivalent of $D$. Rydbergii Schulz var. eglandulosa Schulz ], $2 n=14$ (fig. 12 ). The subspecies of the southern complex studied cytologically-halictorum, glabra, and Menziesiiare tetraploid; halictorum, also having an hexaploid race, is the most widely distributed subspecies in this group. Of the northern subspecies, filipes and Nelsonii are known to be diploid, and intermedia tetraploid. 'The ranges of these three subspecies are about equal in area and coincide to a considerable extent. It is to be remarked that the diploid filipes reaches the northern limit, the tetraploid glabra the southern limit of the species.

In every case during this study that polyploid differences were found within a species, Detling (1939) had already observed phenotypic differences, and to them, except in the case of $D$. pinnata subsp.

'ТавL: 1. Intraspecific relations between polyploidy and size of plant parts.

\begin{tabular}{|c|c|c|c|c|c|c|}
\hline Species: subspecies & $\begin{array}{c}2 n \text {-number } \\
\text { of chromo- } \\
\text { somes }\end{array}$ & $\begin{array}{l}\text { Plant } \\
\text { height } \\
\text { in } c m .\end{array}$ & $\begin{array}{l}\text { Corolla } \\
\text { length } \\
\text { in } \mathrm{mm} \text {. }\end{array}$ & $\begin{array}{l}\text { Calyx } \\
\text { length } \\
\text { in } m m .\end{array}$ & $\begin{array}{l}\text { Silique } \\
\text { length } \\
\text { in } m m \text {. }\end{array}$ & $\begin{array}{l}\text { Fruiting } \\
\text { pedicel } \\
\text { in } m \mathrm{~m} .\end{array}$ \\
\hline \multicolumn{7}{|l|}{ D. Richardsonii } \\
\hline subsp. viscosa $\ldots \ldots$ & 14 & $\ldots \ldots$ & $:-3.5$ & $1.5-2.5$ & $9-15$ & $6-10(12)$ \\
\hline subsp. procera $\ldots \ldots$ & 28 & $\ldots \ldots$ & $1-2$ & $1-1.5$ & $6-12$ & $2-6$ \\
\hline subsp, incisat $\ldots \ldots \ldots$ & 42 & $\ldots \ldots$ & $1.5-2$ & $1-1.5$ & $8-15$ & $4-10$ \\
\hline \multicolumn{7}{|l|}{ D. obtusa } \\
\hline subsp. typied $\ldots \ldots$ & 14 & & $\ldots$ & & $10-20$ & $6-15$ \\
\hline subsp, brevisiliqua ... & 42 & $\ldots \ldots$ & $\ldots$ & $\ldots \ldots$ & $5-9$ & $4-6$ \\
\hline \multicolumn{7}{|l|}{ 1). pinnata } \\
\hline subsp. halictorum ... & $28 \& 4: 2$ & $15-50$ & $\ldots$ & $1-2$ & $5-10$ & $8-1: 2$ \\
\hline subsp. glabra $\ldots \ldots$ & 28 & $10-49$ & $\ldots$ & $0.75-1.5$ & $5-8$ & $4-12$ \\
\hline subsp. intermedia ... & 28 & $20-65$ & $\ldots$ & $1.5-3.5$ & $8-12$ & $6-12$ \\
\hline subsp. Nelsonii ..... & 14 & $10-50$ & $\ldots$ & 1 & $1-8(10)$ & $4-6(8)$ \\
\hline subsp. filipes . . . . . & 14 & $10-65$ & $\cdots$ & $1.5-2.5$ & $10-15(20)$ & $10-15$ \\
\hline
\end{tabular}


halictorum, had given systematic recognition. His treatment thus accords with Mützing's (1936) conclusion "that intraspecific chromosome races are practically always morphologically different from each other." And the resultant cytotaxonomic concept of certain species of Descurainia resembles that of de I.itardière (1939) concerning Poa annua L.

To demonstrate for three Descurainia species the relations between variation in size of characters and degree of intraspecific polyploidy, there are given in table 1 the chromosome numbers determined by the authors for certain subspecies and detailed measurements made by Detling for those same subspecies. Analysis of table 1 shows that in D. Richardsonii the diploid subspecies equals or exceeds both the tetraploid and the hexaploid in length of corolla, calyx, silique, and fruiting pedicel; this is to be correlated with the statement of Detling that subspecies viscosa, which is the diploid, has the largest flowers in the species. Similarly, the diploid subspecies of $I$ ). obtusa has longer fruits and pedicels than the hexaploid. The situation in $D$. pinnata is more complex : of the five subspecies studied, Nelsonii with 1.t somatic chromosomes and glabra with twice that number approximate each other in the measurements given and are smaller in these respects than the other subspecies. Detling discovered that under cultural conditions these two subspecies, Nelsonii and glabra, matured seeds first; the present writers found them to be the earliest to bloom. In contrast to the small-flowered, short-siliqued, short-pedi- celled Nelsonii, subspecies filipes, also diploid, equals or exceeds the other subspecies in the size of each of these characters and likewise in height. Therefore, with regard to the characters considered, sizes within these species a re correlated in no regular fashion with differences in ploidy.

\section{SUMMARY}

Chromosome numbers are reported, from leafsmear determinations, for four species and ten subspecies of Descurainia. The genus has evolved on a 7-chromosome system : diploid, tetraploid, and hexaploid plants occur, polyploidy being often intraspecific.

Detling (1939) observed phenotypic differences that are correlative with polyploid differences discovered during the present study and by those phenotypic differences, except in one instance, made nomenclatorial distinctions.

In some species of Descurainia the polyploid groups occupy the most restricted geographic ranges and, in other species, the greatest ranges. In certain complexes the diploid subspecies tend to be northern in distribution and, in other cases, southern.

Variations in size of characters within species of Descurainia are not regularly correlated with polyploid differences.

\footnotetext{
Departint of Botaxy, CNiverstry or Michigas. Ans Arbor, Michigay
}

\section{LITERATURE CITED}

Baldwin, J. 'T', JR. 1939. Chromosomes from leaves. Science N. S. $90: 240$.

Cockerel., T. D. A. 1901. A new Sophia. Bull. 'Torrey Bot. Club 28: 48-49.

DF IITARbiènF, R. 1939. Sur les caractères chromosomiques et la systématique des Por du groupe du Poa anuиa I.. Rev. Cytolog. et Cytophysiolog. vég. 4: 81-85.

Drarıso, I. E. 1939. A revision of the North American species of Descurainia. Amer. Midl. Nat. $22: 481-5 \geq 0$.

Fersaid, M. I.. 1940. Some spermatophytes of eastern North America. Rhodora 42: 239-276.
JaREtzky, R. 193:2. Beziehungen zwischen Chromosomenzahl und Systematik bei den Cruciferen. Jahrb. wiss. Bot. 76: 485-527.

Manton, Infare. 193:. Introduction to the general cytology of the Cruciferae. Annals Botany 46:509-5;56.

Maror, A. B. 1934. Fstudio cariológuo de algunas crucíferas y su interpretación en la sistemática. Cavanillesia $6: 59-103$.

Mirstasc, $A$. 1936. 'The evolutionary significance of autopolyploidy. Hereditas $21: 263-378$.

Scuviz, O. E. 19:4. Cruciferae-Sisymbrieae. Das Pflanzenreich IV, 105: 1-388. 